\title{
PARBOILED RICE BRAN IN JAPANESE QUAIL DIETS AT GROWING PHASE AND RESIDUAL EFFECT AT LAYING PERIOD
}

\author{
Farelo de arroz parboilizado na alimentação de codornas japonesas em \\ crescimento e seu efeito residual na fase de produção
}

\author{
Ednardo Rodrigues Freitas', Ivan Bezerra Quevedo Filho², Pedro Henrique Watanabe', \\ Thales Marcel Bezerra Filgueira², Carlos Eduardo Braga Cruz ${ }^{2}$, Thaís Cruz Lopes Tavares²
}

\begin{abstract}
Rice is the second largest cereal crop in the world and the by-products resulting from rice processing for human consumption are potential feedstuffs to compose poultry diets. In this sense, it was evaluated the influence of parboiled rice bran (PRB) in diets for Japanese quails in growing phase on the performance and digestibility, besides of residual effects and characteristics of egg quality in laying phase. A total of 324 Japanese quails with 7 days of age were distributed in a completely randomized design, with 6 treatments and 6 replicates of 9 birds. The treatments consisted of 6 isonutritives diets, being a control diet without PRB and the others containing 5,10,15,20 and 25\%. At the end of growing phase the birds were allotted in cages and fed the same diet without PRB at laying phase. At growing phase, the inclusion of PRB up to 5\% promoted linear reduction in dry matter and gross energy digestibilities of diet; however a linear increase in metabolizable energy was noted. Feed intake, weight gain and final weight were reduced but not altering feed:gain ratio and body composition. At laying phase, the inclusion of PRB increased the age at first egg production but no influence was verified at age to reach $50 \%$ of egg production. No effect was verified at laying percentage, feed intake, weight and egg mass and feed:gain ratio. In economical evaluation, the inclusion of up to $25 \%$ of parboiled rice bran provided best economical indexes. The inclusion of PRB Japanese quails diets at growing phase can be recommended in levels up to $25 \%$, without incurring future losses at laying phase.
\end{abstract}

Index terms: Alternative feedstuff, body composition, performance.

\section{RESUMO}

O arroz é a segunda maior cultura cerealífera do mundo e os subprodutos resultantes de seu processamento do arroz para o consumo humano são potenciais ingredientes para compor as rações para aves. Nesse sentido, objetivou-se, neste estudo, avaliar a inclusão de diferentes níveis de farelo integral de arroz parboilizado (FIAP) em rações para codornas japonesas em crescimento quanto à digestibilidade dos nutrientes da dieta, desempenho, maturidade sexual e composição corporal e seus efeitos na fase de postura quanto à produção e características dos ovos. Foram utilizadas 324 codornas japonesas com 7 dias de idade, distribuídas em delineamento inteiramente casualizado, com 6 tratamentos e 6 repetições de 9 aves. Os tratamentos consistiram em 6 rações isonutrientes, sendo uma ração controle, sem FIAP e as demais contendo 5, 10, 15, 20 e 25\% de FIAP. Ao final da fase de crescimento, as aves foram transferidas para o galpão de produção, sendo alimentadas com uma mesma ração de postura por 63 dias, sem inclusão de FIAP. Na fase de crescimento, a inclusão de FIAP acima de 5\% promoveu redução linear na digestibilidade da matéria seca e energia bruta da ração, havendo aumento linear nos valores de energia metabolizável das rações. O consumo de ração, ganho de peso e peso final reduziram sem alterar a conversão alimentar e a composição corporal. Na fase de produção, a adição de FIAP na ração de crescimento aumentou a idade para produção do primeiro ovo, sem influenciar significativamente a idade para atingir $50 \%$ de produção. Não houve efeito sobre percentagem de postura, consumo de ração, peso e massa de ovos e conversão alimentar. Em relação à avaliação econômica, o uso de até $25 \%$ de FIAP proporcionou melhores índices de custo. A inclusão do farelo de arroz na ração para codornas japonesas em fase de crescimento pode ser recomendada em níveis de até $25 \%$, sem prejuízo para a fase de postura.

Termos para indexação: Alimento alternativo, composição corporal, desempenho.

(Received in may 20, 2013 and approved in june 28, 2013)

\section{INTRODUCTION}

In Brazil, the Japanese quail production is an activity in expansion with investments in facilities, qualification of skilled labor, breeding strains and more suitable diets formulation to the potential development of the species (MOURA et al., 2008). Besides the nutritional requirements of poultry, studies evaluating alternative feedstuffs to corn and soybean meal are aimed, finding reduction in production costs.

\footnotetext{
'Universidade Federal do Ceará/UFC - Departamento de Zootecnia - Av. Mister Hull - 2977 - Bloco 807 - $60021-970$ - Fortaleza - CE - Brasil ednardo@ufc.br

2Universidade Federal do Ceará/UFC - Fortaleza - CE - Brasil

3Universidade Federal do Ceará/UFC - Departamento de Zootecnia - Fortaleza - CE - Brasil
}

Ciênc. agrotec., Lavras, v. 37, n. 4, p. 350 - 358, jul./ago., 2013 
Accordingly, in addition to the low cost and availability of feedstuff, there are concerns regarding the maintenance of bird performance at growing and laying phase. In Japanese laying quail production, it is expected at the end of growing period, birds present body weight and sexual maturity at appropriate age (FREITAS et al. 2006). Thus, when using alternative feedstuffs in quail diets, it is necessary to evaluate them not only about nutritional characteristics, but also on body development, warping and formation of reproductive system.

Rice is the second largest grain crop in the world (FOOD AND AGRICULTURE ORGANIZATION-FAO, 2012), whose by-products resulting from the beneficiation and processing for human consumption, having nutritional and energetic composition to compose poultry diets. The main process of rice for human consumption is parboiling, consisting of a thermal process applied before peeling and polishing. Thus, the PRB is the residue after polishing grain presenting no difference in nutritional composition when compared to rice bran, higher level of ether extract and low starch content (LACERDA et al., 2010). However, the presence of antinutritional factors such as fiber, phytates, lipases and anti-proteolytic substances, may limit the use of this feedstuff as ingredient in quail diets, with limited information on using parboiled rice bran on the feeding of quail.

Considering the above, the present study aimed to evaluate the inclusion of PRB in diets of Japanese quail at growing phase and its effects on laying phase.

\section{MATERIAL AND METHODS}

A total of 400 Japanese quail (Coturnix coturnix japonica) sexed with 1 day of age were housed in a protective circle in a conventional poultry shed with tray-type feeder and drinker. The floor was covered with wood shavings bedding and the heating through electric bells. Throughout the experimental period, temperature and relative humidity data were collected daily at $08 \mathrm{~h} 00$ and $16 \mathrm{~h} 00$.

At seven days of age, 324 birds with an average initial weight of $22.45 \mathrm{~g}$ were selected based on the uniformity of weight and distributed in a completely randomized design with 6 treatments and 6 replicates of 9 birds each. Treatments consisted of a control diet (no PRB) and diets with increasing levels of 5, 10, 15, $20 \mathrm{e}$ $25 \%$ of PRB. The experimental diets (Table 1) were formulated to be isonutritive according to the nutritional requirements recommended by the National Research Council - Nrc (1994) for growing quails. For the feed composition it was considered the values presented by Rostagno et al. (2011), correcting to dry matter content, determined according to Association of Offical Analytical Chemists - AOAC (2005).

At the beginning of the experimental period, the animals were housed in galvanized wire cages $(24 \mathrm{~cm} \times 50$ $\mathrm{cm} \times 25 \mathrm{~cm}$ ) with gutter type feeder and nipple drinker. At the tenth day, quail chicks were vaccinated according to the regional vaccination program routine. Throughout the experimental period, the birds received feed and water $\mathrm{ad}$ libitum. At 42 days of age, the birds were weighed and the diet leftovers were measured by replicate, determining the weight gain ( $\left.\mathrm{g} \mathrm{bird}^{-1}\right)$, feed intake $\left(\mathrm{g} \mathrm{bird}^{-1}\right)$ and feed:gain ratio $\left(\mathrm{g} \mathrm{g}^{-1}\right)$. The lighting program adopted during the growing phase was 24 hours of light (natural and artificial), during the first 7 days of the experiment, and natural light during the 35 days remaining.

The effects of PRB inclusion in nutrient digestibility of diets were carried by total excreta collection method (SAKOMURA; ROSTAGNO, 2007) in two periods, from the 14 th to the 18 th day and from 35 th to 39 th day of the trial period. Prior to the start of feeding during this assay, quails were fasted for two hours in order to empty the gastrointestinal tract, and thus only collect the excreta corresponding to feed consumed during the test. The same procedure was performed to determine the end of the collection period.

In each period, excreta were collected twice a day (08h00 and 16h00) in trays covered with plastic and placed under each cage. After the collection period, samples were properly identified and dried at $55^{\circ} \mathrm{C}$ for 72 hours. Then, excreta and experimental diets samples were grinded, sent to the laboratory and analyzed for dry matter (DM), nitrogen (N) and gross energy (GE), according to AOAC (2005). Based on laboratory analysis, apparent digestibility of DM, $\mathrm{N}$, GE and apparent metabolizable energy (AME) and apparent corrected for nitrogen balance (AMEn) were calculated, according to the equations proposed by Matterson et al. (1965).

At 42 days of age, two birds per replicate were selected based on the weight of the parcel to determine the body composition. After 4 hours of fasting, they were slaughtered and placed in plastic bags and carried into the freezer $\left(-20^{\circ} \mathrm{C}\right)$, until the time of processing for obtaining the samples. Samples of each whole bird for analysis of body composition were obtained after autoclaving $\left(127^{\circ} \mathrm{C}\right.$, 1 atm for 2 hours) and homogenized in a domestic food processor. After processing, the samples dried at $55^{\circ} \mathrm{C}$ for 72 hours, grinded and analyzed for dry matter (DM), nitrogen (N) and gross energy (GE), according to AOAC (2005).

At the end of the growing phase (42 days), the remaining birds were transferred to the production house, 
using the same initial experimental design. In this phase, birds from each plot were housed in galvanized wire cages $(33 \mathrm{~cm} \times 23 \mathrm{~cm} \times 16 \mathrm{~cm})$, containing gutter type feeder and nipple drinker. During the laying phase, all birds were fed same diet without the addition of PRB (Table 1). During this phase, quails were subjected to an initial stimulus of 14 hours of light, with weekly increments of 15 minutes to complete 16 hours (natural and artificial light).
During the laying phase, the experimental period were divided into three periods of 21 days each. Egg production was recorded daily by cage and at the end of each period, diet leftovers were quantified to determine the feed intake (FI). The evaluation of sexual maturity was performed by counting the days for the first egg laid and number of days to reach $50 \%$ of laying by birds per replicate.

Table 1 - Chemical composition of Japanese quail diets from 7 to 42 days of age and at laying phase.

\begin{tabular}{|c|c|c|c|c|c|c|c|}
\hline \multirow{2}{*}{ Feedstuffs (kg) } & \multicolumn{6}{|c|}{ Parboiled rice bran level (\%) } & \multirow{2}{*}{$\begin{array}{c}\text { Laying } \\
\text { phase }\end{array}$} \\
\hline & 0 & 5 & 10 & 15 & 20 & 25 & \\
\hline Corn & 52.10 & 47.01 & 41.94 & 36.85 & 31.77 & 26.67 & 55.60 \\
\hline Parboiled rice bran & 0.0 & 5.00 & 10.00 & 15.00 & 20.00 & 25.00 & 0.00 \\
\hline Soybean meal (45\%) & 42.99 & 42.46 & 41.93 & 41.39 & 40.86 & 40.33 & 33.96 \\
\hline Limestone & 1.20 & 1.22 & 1.25 & 1.27 & 1.29 & 1.32 & 5.16 \\
\hline Soybean oil & 1.91 & 2.56 & 3.20 & 3.86 & 4.51 & 5.17 & 2.88 \\
\hline Monobicalcium phosphate & 1.59 & 1.53 & 1.47 & 1.42 & 1.35 & 1.29 & 1.59 \\
\hline Vitamin and mineral supplement $^{\mathrm{a}}$ & 0.40 & 0.40 & 0.40 & 0.40 & 0.40 & 0.40 & 0.00 \\
\hline Vitamin and mineral supplement ${ }^{\mathrm{b}}$ & 0.00 & 0.00 & 0.00 & 0.00 & 0.00 & 0.00 & 0.50 \\
\hline Salt & 0.44 & 0.44 & 0.44 & 0.44 & 0.44 & 0.44 & 0.28 \\
\hline DL-methionine & 0.03 & 0.03 & 0.03 & 0.03 & 0.03 & 0.03 & 0.03 \\
\hline Total & 100.00 & 100.00 & 100.00 & 100.00 & 100.00 & 100.00 & 100.00 \\
\hline \multirow[t]{2}{*}{ Feed cost $(\mathrm{R} \$ / \mathrm{kg})$} & 0.95 & 0.95 & 0.95 & 0.94 & 0.94 & 0.93 & 0.97 \\
\hline & \multicolumn{6}{|c|}{ Calculated nutritional composition } & \\
\hline Metabolizable energy $\left(\mathrm{kcal} \mathrm{kg}^{-1}\right)$ & 2.900 & 2.900 & 2.900 & 2.900 & 2.900 & 2.900 & 2.900 \\
\hline Crude protein $(\%)$ & 23.80 & 23.80 & 23.80 & 23.80 & 23.80 & 23.80 & 20.00 \\
\hline Ether extract $(\%)$ & 4.49 & 5.67 & 6.85 & 8.06 & 9.25 & 10.45 & 5.42 \\
\hline Acid detergent fiber $(\%)$ & 5.35 & 5.75 & 6.16 & 6.56 & 6.97 & 7.38 & 4.74 \\
\hline Neutral detergent fiber $(\%)$ & 12.08 & 12.47 & 12.86 & 13.26 & 13.65 & 14.04 & 11.23 \\
\hline Calcium (\%) & 0.80 & 0.79 & 0.80 & 0.80 & 0.80 & 0.80 & 2.50 \\
\hline Available phosphorus (\%) & 0.30 & 0.30 & 0.30 & 0.30 & 0.30 & 0.30 & 0.40 \\
\hline Total Lysine (\%) & 1.32 & 1.32 & 1.32 & 1.32 & 1.32 & 1.32 & 1.10 \\
\hline Total methionine + cystine $(\%)$ & 0.87 & 0.87 & 0.87 & 0.87 & 0.87 & 0.87 & 0.77 \\
\hline Total Threonine $(\%)$ & 0.92 & 0.92 & 0.92 & 0.92 & 0.92 & 0.92 & 0.78 \\
\hline Total Tryptophan (\%) & 0.30 & 0.30 & 0.30 & 0.30 & 0.30 & 0.30 & 0.25 \\
\hline
\end{tabular}

${ }^{a}$ Composition per kg of the product: folic acid $-138.00 \mathrm{mg}$; calcium pantothenate $-2,750.00 \mathrm{mg}$; antioxidant $-500.00 \mathrm{mg}$; biotin

- $13.80 \mathrm{mg}$; cobalt - $25.00 \mathrm{mg}$; copper - 2,500.00 mg; choline - 111,450.00 mg; iron - 6,250.00 mg; iodine - 260.00 mg; manganese - 13,000.00 mg; methionine - $300 \mathrm{~g}$; niacin - 6,875.00 mg; piridoxine - $550.00 \mathrm{mg}$; colistin - 1,750.00 mg; riboflavin - 1,375.00 mg; selenium - $45.00 \mathrm{mg}$; thiamine - $550.00 \mathrm{mg}$; vit. A - 2,150,000.00 UI; vit. B12 - 2,750.00 $10^{3} \mathrm{mg}$; vit. D3 - 555,000.00 UI; vit. E 2,750.00 UI; vit. K - $400.00 \mathrm{mg}$; zinc - $11,100.00 \mathrm{mg}$; silicates - 20,000.00 mg.

${ }^{\mathrm{b}}$ Composition per kg of the product: folic acid $-400.00 \mathrm{mg}$; calcium pantothenate - 3,000.00 mg; antioxidant - 2,000.00 mg; biotin - $10.00 \mathrm{mg}$; copper - 2,000.00 mg; choline - 126,000.00 mg; iron - 20,000.00 mg; iodine - $200.00 \mathrm{mg}$; manganese - 18,000.00 mg; methionine - 217,800.00 mg; niacin - 7,000.00 mg; piridoxine - $800.00 \mathrm{mg}$; colistin - 1,400.00 mg; riboflavin - 1,200.00 mg; selenium - $100.00 \mathrm{mg}$; thiamine - $800.00 \mathrm{mg}$; vit. A - 2,000.000 UI; vit. B12-1,000 $10^{3} \mathrm{mg}$; vit. D3 - 500,000.00 UI; vit. E - 1,000.00 UI; zinc - 14,000.00 mg; menadione - $500.00 \mathrm{mg}$; bacitracin zinc - 10,000.00 mg. 
At the end of each period, egg production and laying percentage were measured per replicate. The laying percentage was calculated by dividing the number of eggs produced by the number of birds multiplied by 100 . The average egg weight was obtained by dividing the total weight by the number of eggs collected per replicate. The egg mass was calculated by multiplying the number of eggs produced by the average egg weight for each replicate. The feed conversion was calculated by dividing the feed intake by the egg mass.

The economic evaluation of the inclusion of PRB in diets was determined by the cost of the diet (CD) per kilogram of live weight gain, according to the equation proposed by Bellaver et al. (1985), Yi = (Qi × Pi) / Gi, where $\mathrm{Yi}=$ cost of feed per kilogram of weight gain in the ith treatment; Qi = amount of feed intake in the ith treatment, $\mathrm{Pi}=$ price per kilogram the feed used in the ith treatment and $\mathrm{Gi}=$ weight gain of the ith treatment. Then, economic efficiency index (EEI) and the cost index (CI) were calculated according to Fialho et al. (1992), IEE = (LCei / S, TeI) and CI $=100 \times(\mathrm{S}, \mathrm{TeI} / \mathrm{LCei}) \times 100$, where LCei $=$ lower cost of feed per kilogram observed between treatment and $\mathrm{S}, \mathrm{TeI} i=$ the cost of treatment considered. The costs of the diets were determined considering their compositions and the prices of feedstuffs obtained in jan. 2011 in the city of Fortaleza, Ceará State.
Statistical analyzes of data were performed using PROC GLM of SAS (2000). Data were subjected to analysis of variance according to a complete randomized design and the degrees of freedom regarding the inclusion levels of PRB, excluding the control diet (zero level of inclusion), were deployed in a polynomial curve to establish the best description of data analysis and thus, when possible, determine the best level of the PRB inclusion. Dunnett test at $5 \%$ of probability was used to compare the results obtained at each level of PRB with the control diet.

\section{RESULTS AND DISCUSSION}

Minimum and maximum temperature and relative humidity in the shed during the experiment were $26.22+$ $1.53^{\circ} \mathrm{C}, 30.61^{\circ} \mathrm{C}+2.16$ and $78 \%$, respectively.

The inclusion of PRB at levels above 5\% linearly reduced the digestibility of dry matter $(\mathrm{CDDM})(\mathrm{Y}=80.06$ $\left.-0.17 X, R^{2}=0.65\right)$ and gross energy (CDGE) $(Y=82.44$ $\left.0.12 \mathrm{X}, \mathrm{R}^{2}=0.87\right)$. A quadratic effect on the digestibility of nitrogen $(\mathrm{CDN})\left(\mathrm{Y}=47.39+2.57 \mathrm{X}-0.09 \mathrm{X}^{2}, \mathrm{R}^{2}=0.74\right)$ was observed, with the maximum point estimate for $14.27 \%$ of inclusion parboiled rice bran, while the values of AME (Y $\left.=16.64+3.419 \mathrm{X}, \mathrm{R}^{2}=0.96\right)$ and $\mathrm{AMEn}(\mathrm{Y}=15.50+3.308 \mathrm{X}$, $\mathrm{R}^{2}=0.95$ ) raised linearly as increasing level of this feedstuff in diet (Table 2).

Table 2 - Coefficients of digestibility and energy values of Japanese quail diets with different levels of parboiled rice bran.

\begin{tabular}{|c|c|c|c|c|c|}
\hline Parboiled rice bran level (\%) & $\begin{array}{c}\text { CDDM } \\
(\%)\end{array}$ & $\begin{array}{c}\mathrm{CDN} \\
(\%) \\
\end{array}$ & $\begin{array}{c}\text { CDGE } \\
(\%)\end{array}$ & $\begin{array}{c}\text { AME } \\
\left(\mathrm{kcal} \mathrm{kg}^{-1} \mathrm{MS}\right)\end{array}$ & $\begin{array}{c}\text { AMEn } \\
\left(\mathrm{kcal} \mathrm{kg}^{-1} \mathrm{MS}\right)\end{array}$ \\
\hline 0 & 76.52 & 53.55 & 78.03 & 3.326 & 3.237 \\
\hline 5 & 78.74 & 56.90 & $81.41 *$ & $3.507^{*}$ & $3.367 *$ \\
\hline 10 & 79.21 & $66.94 *$ & $81.71 *$ & $3.535^{*}$ & $3.439 *$ \\
\hline 15 & 76.47 & $60.72 *$ & 80.75 & $3.727 *$ & $3.595^{*}$ \\
\hline 20 & 77.87 & $63.19 *$ & 79.63 & $3.763 *$ & $3.644 *$ \\
\hline 25 & 75.10 & 52.43 & 79.33 & $3.809 *$ & $3.660 *$ \\
\hline Mean & 77.32 & 58.95 & 80.14 & 3.611 & 3.490 \\
\hline Effects - ANOVA & & & $p$-value & & \\
\hline Level & 0.05 & 0.001 & 0.001 & 0.03 & 0.001 \\
\hline Regression analysis & & & $p$-value & & \\
\hline Linear & 0.02 & 0.11 & 0.02 & 0.001 & 0.001 \\
\hline Quadratic & 0.56 & 0.001 & 0.64 & 0.134 & 0.124 \\
\hline $\mathrm{CV}(\%)$ & 3.15 & 6.41 & 2.47 & 1.18 & 1.23 \\
\hline
\end{tabular}


Although no difference was observed in CDDM between diets with PRB compared to the control diet, higher values for $\mathrm{CDN}$ diets containing 10,15 and $20 \%$ of this feedstuff were founded, possibly due to the effect of parboiling process on quality and availability of the protein, with consequent improvement in digestibility. Regarding energy, higher values of CDGE in diets containing 5 and $10 \%$ of PRB over the control diet were observed. Furthermore, the increased energy concentration of the diet was possibly due to an underestimation of the metabolizable energy of PRB since it has been considered the energy value of rice bran presented by Rostagno et al. (2011). Thus, for isoenergetic diets and increased level of PRB in diet, higher amount of soybean oil was used, and consequently, an increase in the fat content was available to the Japanese quails. To increase the metabolizable energy of the feedstuff, the availability of fat may have contributed for digestion and the largest exposure of this fraction by thermal processing of parboiling (DORS; PINTO; BADIALE-FURLONG, 2009), increasing the availability of this content for animals.

Regarding performance, the inclusion of PRB at levels above 5\% linearly reduced $(\mathrm{P}<0.05)$ in feed intake at initial phase $\left(Y=180.19-0.67 X, R^{2}=0.88\right)$ and total period $\left(\mathrm{Y}=537.12-2.06 \mathrm{X}, \mathrm{R}^{2}=0.56\right)$ as well as the weight gain at initial phase $\left(\mathrm{y}=70.74\right.$ to $\left.0.16 \mathrm{X}, \mathrm{R}^{2}=0.83\right)$ and total period $\left(Y=116.13-0.41 X, R^{2}=0.72\right)$. However, feed:gain ratiodid not vary significantly among the levels tested for both periods (Table 3).

Table 3 - Performance of Japanese quail fed diets with different levels of parboiled rice bran.

\begin{tabular}{|c|c|c|c|}
\hline Parboiled rice bran level (\%) & Feed intake $\left(\mathrm{g} \mathrm{bird}^{-1}\right)$ & Weight gain $\left(\mathrm{g} \mathrm{bird}^{-1}\right)$ & Feed conversion ratio $\left(\mathrm{g} \mathrm{g}^{-1}\right)$ \\
\hline \multicolumn{4}{|c|}{7 to 21 days of age } \\
\hline 0 & 188.67 & 70.21 & 2.69 \\
\hline 5 & 178.48 & 71.41 & 2.50 \\
\hline 10 & 166.46 & 67.78 & 2.45 \\
\hline 15 & 173.76 & 66.97 & 2.59 \\
\hline 20 & 174.26 & 68.04 & 2.56 \\
\hline 25 & $161.92 *$ & $67.41 *$ & 2.40 \\
\hline Mean & 242.15 & 103.22 & 2.35 \\
\hline Effects - ANOVA & & $p$-value & \\
\hline Level & 0.04 & 0.01 & 0.39 \\
\hline Regression analysis & & $p$-value & \\
\hline Linear & 0.04 & 0.02 & 0.43 \\
\hline Quadratic & 0.79 & 0.06 & 0.23 \\
\hline $\mathrm{CV}^{\mathrm{b}}(\%)$ & 9.82 & 3.36 & 9.63 \\
\hline \multicolumn{4}{|c|}{7 to 42 days of age } \\
\hline 0 & 519.61 & 106.71 & 4.88 \\
\hline 5 & $537.20 *$ & $116.03 *$ & 4.65 \\
\hline 10 & 494.35 & 109.88 & 4.51 \\
\hline 15 & 512.06 & 108.36 & 4.73 \\
\hline 20 & 508.91 & 110.13 & 4.63 \\
\hline 25 & 476.89 & 105.69 & 4.52 \\
\hline Mean & 509.01 & 109.57 & 4.66 \\
\hline Effects - ANOVA & & $p$-value & \\
\hline Level & 0.03 & 0.04 & 0.06 \\
\hline Regression analysis & & $p$-value & \\
\hline Linear & 0.01 & 0.04 & 0.13 \\
\hline Quadratic & 0.19 & 0.56 & 0.56 \\
\hline $\mathrm{CV}^{\mathrm{b}}(\%)$ & 6.30 & 4.60 & 8.28 \\
\hline
\end{tabular}

ANOVA = Analysis of variance; $\mathrm{CV}=$ Coefficient of variation; $*$ Observed difference compared to control diet $(0 \%$ of inclusion $)$ by Dunnet test $(\mathrm{p}<0.05)$.

Ciênc. agrotec., Lavras, v. 37, n. 4, p. 350 - 358, jul./ago., 2013 
Comparing the different inclusion levels of PRB to control diet (Dunnett, 5\%), it was noted that during the initial phase (7-21 days) only the birds fed $25 \%$ of PRB presented feed intake and weight gain significantly lower than obtained for birds fed diet without this feedstuff. However, during the total period (7-42 days), the same effect was not observed, and found that birds fed 5\% of PRB presented higher feed intake and weight gain compared to those fed control diet.

The inclusion of this feedstuff at levels above 5\% caused a linear reduction in final weight of birds $(\mathrm{Y}=$ $138.87-0.34 \mathrm{X}, \mathrm{R}^{2}=0.73$ ). However, this effect was not sufficient to cause any change in body composition of birds at 42 days of age, in order that there was no significant effect of PRB inclusion on dry matter, crude protein and ether extract body content of Japanese quails at growing phase, nor difference between the results obtained for different levels of PRB and those obtained for the control group (Table 4).

The feed intake reduction with increasing level of PRB above 5\% could be due to the metabolizable energy of feed, and according to Leeson and Summers (2001), birds regulate the voluntary feed intake, within certain limits, trying to regulate the energy intake. Considering weight gain as a result of the ingestion and absorption of nutrients by the birds, the reduction in weight gain may be associated to reduction in feed intake as the level of PRB in diet. On the other hand, as the weight gain was proportional to food intake, feed:gain ration did not differ. However, although it has been observed effect on weight gain and final body weight of birds fed different levels of PRB, no change was observed in body composition of birds at the end of growing phase.

Evaluating the sexual maturity of Japanese quails (Table 5), the inclusion of PRB at levels above $5 \%$ promoted linear increase $(\mathrm{P}<0.05)$ on age at first egg laid $\left(\mathrm{Y}=46.04+037 \mathrm{X}, \mathrm{R}^{2}=0.69\right)$ but did not influence the number of days to reach $50 \%$ of egg production.

It was not observed significant effect $(\mathrm{P}>0.05)$ on performance and number of days to reach $50 \%$ of laying in function of treatments. However, a significant variation $(\mathrm{P}<0.05)$ on sexual maturity of the birds fed diets containing $5 \%$ of this feedstuff was observed, being more precocious than the control group.

The age at first egg laid has been used to characterize the sexual maturity of birds and this can be influenced by several factors such as genetic, chronological age, body weight and body composition. In this context, birds that had higher body weight at sexual maturity will have better performance, and those with low body weight will present maturity later and decreased performance (BRAZ et al., 2011). In the present work, quails fed diet with $5 \%$ of PRB were heavier at the end of the growing phase and hence earlier sexual

Tabela 4 - Body weight and chemical composition of Japanese quail at growing phase.

\begin{tabular}{|c|c|c|c|c|}
\hline Parboiled rice bran level (\%) & Body weight (g) & Dry matter $(\%)$ & Crude protein $(\%)$ & Ether extract (\%) \\
\hline 0 & 130.31 & 33.54 & 23.03 & 8.02 \\
\hline 5 & $137.84 *$ & 34.66 & 22.93 & 8.35 \\
\hline 10 & 133.51 & 35.07 & 23.49 & 8.08 \\
\hline 15 & 131.88 & 33.56 & 22.96 & 7.82 \\
\hline 20 & 133.76 & 35.71 & 23.80 & 8.00 \\
\hline 25 & 129.02 & 33.56 & 23.38 & 7.77 \\
\hline Mean & 132.88 & 34.37 & 23.26 & 8.00 \\
\hline Effects - ANOVA & & $p$-value & & \\
\hline Level & 0.04 & 0.19 & 0.25 & 0.91 \\
\hline Regression analysis & & $p$-value & & \\
\hline Linear & 0.03 & 0.58 & 0.21 & 0.29 \\
\hline Quadratic & 0.56 & 0.67 & 0.59 & 0.72 \\
\hline CV $(\%)$ & 3.12 & 5.18 & 3.11 & 11.68 \\
\hline
\end{tabular}

ANOVA $=$ Analysis of variance $; \mathrm{CV}=$ Coefficient of variation; $*$ Observed difference compared to control diet $(0 \%$ of inclusion) by Dunnet test $(\mathrm{p}<0.05)$. 
maturity in relation to those fed the control diet. Likewise, a linear increase in the age at first egg laid was observed when the birds were fed PRB at levels above $5 \%$ in the diet.

In some researches it has been observed that lighter birds at the end of growing phase showed lower egg mass production and impaired feed conversion at laying phase (ARAÚJO et al., 2008). Thus, there is concern with suitable body weight at beginning of laying period to Japanese quails. In this context, it was expected that the body weight of quails at the end of the growing phase had effects on laying phase. However, it can be seen that the effects of feed received during growth did not influenced the production, weight and egg mass and feed conversion during the laying phase.

Results similar to those obtained have been reported for laying hens (BARROS et al., 2006; BRAZ et al. 2011). According to researchers, although the treatments have significantly influenced the weight gain of pullets at growing phase, feed intake, egg mass and production and feed conversion at laying period did not differ significantly. Similarly, Abubakar et al. (2011) observed that feeding diets containing up to $50 \%$ of rice bran during the growing phase does not adversely affect age at point of lay and the onset of laying and performance of brown pullets.

In regression analysis, it was observed no effect of PRB inclusion in diets on feed cost per kilogram of weight gain, cost index and economic efficiency index (Table 6). However, comparing the results obtained with different levels of PRB to control diet, the inclusion of $25 \%$ of this feedstuff presented lower cost per kilogram of weight gain, cost index and higher economic efficiency index. Due to the cost of PRB presented approximately $91.43 \%$ of corn cost, this difference made it possible to increase the proportion of oil in the feed to maintain the same level of nutrients and energy. Moreover, considering the possibility of metabolizable energy of PRB being underestimated, that would imply in smaller inclusion of oil in the diet and, therefore, reduction on feed cost, allowing the feasibility of PRB higher levels of inclusion. The determination of correct energy value of parboiled rice bran for quail should be studied in further research and thus, using this value in diet formulation and being possible to assess the impact of adding that feedstuff in Japanese quail diets.

Table 5 - Sexual maturity and performance of Japanese quails at laying phase.

\begin{tabular}{|c|c|c|c|c|c|c|c|}
\hline $\begin{array}{l}\text { Parboiled rice } \\
\text { bran level }(\%)\end{array}$ & $\begin{array}{c}\mathrm{AFE} \\
\text { (days) }\end{array}$ & $\begin{array}{l}\text { AR50\% } \\
\text { (days) }\end{array}$ & $\begin{array}{c}\text { FI } \\
\left(\text { g bird }^{-1} \text { day }^{-1}\right)\end{array}$ & $\begin{array}{c}\text { Production } \\
(\%)\end{array}$ & $\begin{array}{c}\text { Egg } \\
\text { weight }(g)\end{array}$ & $\begin{array}{c}\text { Egg mass } \\
\left(\mathrm{g} \mathrm{bird}^{-1} \text { day }^{-1}\right)\end{array}$ & $\begin{array}{c}\mathrm{FC}^{\mathrm{d}} \\
\left(\mathrm{g} \mathrm{g}^{-1}\right)\end{array}$ \\
\hline 0 & 53 & 64 & 17.26 & 68.70 & 10.57 & 7.27 & 2.38 \\
\hline 5 & $46^{*}$ & 63 & 16.89 & 75.67 & 10.71 & 8.11 & 2.09 \\
\hline 10 & 52 & 62 & 18.63 & 69.38 & 10.47 & 7.27 & 2.41 \\
\hline 15 & 51 & 61 & 15.77 & 73.06 & 10.58 & 7.73 & 2.06 \\
\hline 20 & 55 & 65 & 17.62 & 71.08 & 10.50 & 7.45 & 2.38 \\
\hline 25 & 54 & 64 & 16.46 & 78.78 & 10.60 & 8.39 & 1.99 \\
\hline Mean & 52 & 63 & 17.11 & 72.82 & 10.55 & 7.69 & 2.23 \\
\hline Effects - ANOVA & \multicolumn{7}{|c|}{$p$-value } \\
\hline Level & 0.01 & 0.81 & 0.79 & 0.25 & 0.92 & 0.34 & 0.36 \\
\hline Regression analysis & \multicolumn{7}{|c|}{$p$-value } \\
\hline Linear & 0.001 & 0.49 & 0.57 & 0.13 & 0.79 & 0.22 & 0.18 \\
\hline Quadratic & 0.15 & 0.54 & 0.70 & 0.47 & 0.75 & 0.44 & 0.66 \\
\hline $\mathrm{CV}(\%)$ & 7.34 & 7.78 & 12.39 & 10.26 & 3.81 & 11.10 & 11.21 \\
\hline
\end{tabular}

$\mathrm{AFE}=$ Age at first egg laid; AR50\% $=$ Age to reach 50\% of egg production; FI = Feed intake; FC = Feed conversion; ANOVA = Analysis of variance; $\mathrm{CV}=$ Coefficient of variation; * Observed difference compared to control diet $(0 \%$ of inclusion) by Dunnet test $(\mathrm{p}<0.05)$. 
Table 6 - Economic evaluation of parboiled rice bran in Japanese quail diets.

\begin{tabular}{|c|c|c|c|c|}
\hline Parboiled rice bran level (\%) & Feed cost $\left(\mathrm{US} \$ \mathrm{~kg}^{-1}\right.$ & weight gain) & Economic efficiency index $(\%)$ & Cost index (\%) \\
\hline \multicolumn{5}{|c|}{7 to 21 days } \\
\hline 0 & 4.27 & & 86.07 & 117.00 \\
\hline 5 & 3.94 & & 92.87 & 107.87 \\
\hline 10 & 3.84 & & 96.31 & 104.94 \\
\hline 15 & 4.02 & & 91.81 & 109.94 \\
\hline 20 & 3.92 & & 94.22 & 107.54 \\
\hline 25 & $3.66^{*}$ & & $100.00 *$ & $100.00 *$ \\
\hline Effects - ANOVA & & & $p$-value & \\
\hline Level & 0.02 & & 0.03 & 0.02 \\
\hline Regression analysis & & & $p$-value & \\
\hline Linear & 0.41 & & 0.50 & 0.40 \\
\hline Quadratic & 0.30 & & 0.37 & 0.30 \\
\hline $\mathrm{CV}^{\mathrm{b}}(\%)$ & 9.62 & & 9.08 & 9.62 \\
\hline \multicolumn{5}{|c|}{7 to 42 dias } \\
\hline 0 & 7.77 & & 87.45 & 114.85 \\
\hline 5 & 7.33 & & 92.89 & 108.40 \\
\hline 10 & 7.05 & & 96.29 & 104.17 \\
\hline 15 & 7.33 & & 93.04 & 108.37 \\
\hline 20 & 7.11 & & 95.88 & 105.10 \\
\hline 25 & $6.76^{*}$ & & $100.00 *$ & $100.00 *$ \\
\hline Effects - ANOVA & & & $p$-value & \\
\hline Level & 0.02 & & 0.01 & 0.02 \\
\hline Regression analysis & & & $p$-value & \\
\hline Linear & 0.67 & & 0.68 & 0.68 \\
\hline Quadratic & 0.48 & & 0.48 & 0.49 \\
\hline $\mathrm{CV}(\%)$ & 8.34 & & 7.85 & 8.34 \\
\hline
\end{tabular}

ANOVA = Analysis of variance; $\mathrm{CV}=$ Coefficient of variation; *Observed difference compared to control diet $(0 \%$ of inclusion $)$ by Dunnet test $(\mathrm{p}<0.05)$.

\section{CONCLUSION}

In conclusion, PRB may be used in Japanese quail diets at growing phase up to $25 \%$ of inclusion, without incurring future losses at laying phase.

\section{REFERENCES}

ABUBAKAR, A. et al. Assessment of yeast supplementation on the onset of laying and subsequent performance of Shika brown layers fed high levels of rice bran during growing period.

International Journal of Applied Agricultural and Apicultural Research, Ogbomosho, v.7, n.2, p.118127, 2011.

\section{ASSOCIATION OF OFFICIALANALYTICAL}

CHEMISTS - AOAC. Official Methods of Analysis. 18ed. AOAC, Gaithersburg, MD, USA. 2005, 1117p.

ARAÚJO, D.M. et al. Farelo de trigo na alimentação de poedeiras semipesadas na fase de recria. Revista Brasileira de Zootecnia, Brasília, v.37, n.1, p.67-72, 2008.

BARROS, L.R. et al. Níveis de proteína para frangas semipesadas no período de uma a dezoito semanas de idade. Ciência Animal Brasileira, Goiânia, v.7, n.2, p.131-141, 2006. 
BRÁZ, N.M. et al. Fibra na ração de crescimento e seus efeitos no desempenho de poedeiras nas fases de crescimento e postura. Revista Brasileira de Zootecnia, Brasília, v.40, n.12, p.2744-2753, 2011.

BELLAVER, C. et al. Radícula de malte na alimentação de suínos em crescimento e terminação. Pesquisa

Agropecuária Brasileira, Brasília, v.20, n.8, p.969-974, 1985.

DORS, G.C; PINTO, R.H; BADIALE-FURLONG E.

Influência das condições de parboilização composição química do arroz. Ciência e Tecnologia de Alimentos, Campinas, v.29, n1, p. 219-224, 2009.

FOODAND AGRICULTURE ORGANIZATION-FAO. 2012. [FAOSTAT] Disponível em: http://faostat.fao.org/. Acesso em: 07 ago. 2012.

FREITAS, E.R. et al. Farelo da castanha de caju em rações para frangos de corte. Pesquisa Agropecuária Brasileira, Brasília, v.41, n.6, p.1001-1006, 2006.

LACERDA, D.B.C.L. et al. Qualidade de farelos de arroz cru, extrusado e parboilizado. Pesquisa
Agropecuária Tropical, Goiânia, v.40, n.4., p.521-530, 2010.

MOURA, G.S. et al. Dietas de diferentes densidades energéticas mantendo constante a relação energia metabolizável:nutrientes para codornas japonesas em postura. Revista Brasileira de Zootecnia, Brasília, v.37, n.9, p.1628-1633, 2008.

NATIONAL RESEARCH COUNCIL - NRC. Nutrient requirements of poultry. 9.ed. Washington: National Academy Press, 1994, 155p.

ROSTAGNO, H.S. et al. Tabelas brasileiras para aves e suínos: Composição de alimentos e exigências nutricionais. 2. ed. Viçosa: UFV, 2011, 186p.

SAKOMURA, N.K.; ROSTAGNO, H.S. Métodos de pesquisa em nutrição de monogástricos. Jaboticabal: Funep, 2007, 283p.

SAS. Statistical analysis system user's guide. Release 8.0. Cary: SAS Institute, 2000. 1 CD-ROM. 